Sains Malaysiana 50(9)(2021): 2591-2602

http://doi.org/10.17576/jsm-2021-5009-08

\title{
In-silico Characterization and Expression Analysis of NB-ARC Genes in Response to Erwinia mallotivora in Carica papaya
}

(Pencirian In-silico dan Analisis Pengekspresan Gen NB-ARC sebagai Gerak Balas kepada Erwinia mallotivora pada Carica papaya)

Nur Syazana Abu BaKar, Noor Baity Saidi, Lina Rozano, Mohd PuAd Abdullah \& SuHaina Supian*

\section{ABSTRACT}

Disease resistance in plants is commonly associated with resistance $(R)$ genes that encode nucleotide binding siteleucine rich repeat (NBS-LRR) domains that are essential for pathogen recognition and defence signalling. In this study, we identified and analyzed the sequence of putative pathogen-responsive NB-ARC transcripts from Carica papaya transcriptome database, carried out the structural and phylogenetic analysis, and determined the expression profile of the transcripts in C. papaya challenged with Erwinia mallotivora. The findings indicate CpNBS1, the only pathogenresponsive NB-ARC protein identified in this study belongs to the CC-NBS-LRR group. Semi-quantitative PCR showed CPNBS1 was differentially expressed in response to E. mallotivora. Structural analysis of the 4993-Eksotika and 4993-Viorica translated proteins showed striking differences in terms of the number of $\beta$-sheets and $\alpha$-helixes as well their ligand-binding surface, suggesting the role of the LRR domain in determining the specificity of recognition of $\mathrm{E}$. mallotivora effector. Collectively, this study provides new insights into the role of NBS-LRR genes in C. papaya and its implications for enhancing plant disease resistance through genetic engineering.

Keywords: E. mallotivora; nucleotide binding site-leucine rich repeat; resistance gene

\section{ABSTRAK}

Kerintangan penyakit pada tumbuhan sering dikaitkan dengan gen kerintangan (R) yang mempunyai domain tapak pengikat nukleotida-ulangan kaya leusina (NBS-LRR) yang berperanan untuk mengenal pasti patogen dan isyarat pertahanan. Dalam kajian ini, kami mengenal pasti dan menganalisis jujukan daripada pangkalan data transkriptom Carica papaya, menjalankan analisis struktur dan filogenetik serta memprofil pengekspresan transkrip C. papaya yang telah dicabar dengan Erwinia mallotivora. Keputusan kajian ini menunjukkan bahawa CpNBS1 adalah satu-satunya protein yang bergerak balas terhadap patogen dan berada dalam kumpulan CC-NBS-LRR. Analisis separa-kuantitatif PCR menunjukkan bahawa CPNBS1 telah diungkapkan secara berbeza sebagai gerak balas kepada E. mallotivora. Analisis struktur pula menunjukkan perbezaan yang nyata daripada segi bilangan kepingan beta dan heliks alfa serta permukaan ikatan ligan, yang mencadangkan peranan domain LRR dalam menentukan ketepatan pengecaman efektor E. mallotivora. Secara keseluruhannya, kajian ini mendedahkan pandangan baharu fungsi gen NBS-LRR dalam C. papaya dan kesannya kepada penambahbaikan kerintangan penyakit dalam tumbuhan melalui kejuruteraan genetik.

Kata kunci: E. mallotivora; gen kerintangan; tapak pengikat nukleotida-ulangan kaya leusina

\section{INTRODUCTION}

Disease resistance in plants is commonly associated with resistance $(\mathrm{R})$ genes that encode nucleotide binding siteleucine rich repeat (NBS-LRR) domains that are essential for pathogen recognition and defence signaling. Most NBS-LRR proteins comprise four distinct domains: a variable amino-terminal domain, NBS domain, LRR domain and variable carboxy-terminal domain that are joint 
by a linker (Steele et al. 2019). Variation in the aminoterminal of NBS-LRR proteins defines the sub-families of these proteins either as a coiled-coil (CC) domain or tolllike interleukin (TIR) domain. This terminal serves as an interaction platform for downstream signaling (Bayless \& Nishimura 2020). The central NBS domain, also known as NB-ARC domain consists of several highly conserved motifs characteristics of the Signal Transduction ATPases with Numerous Domains (STAND) such as P-loop, kinase-2 and Gly-Leu-Pro-Leu motifs. NB-ARC function as molecular switches in disease signaling pathways by catalyzing the hydrolysis of ATP (Zhou et al. 2019). The LRR domain is a highly adaptable structural domain that characteristically contain a series of $\beta$-sheets. This domain is involved in protein-protein interactions and is diverse to fit the binding specificities of various pathogens (Wang et al. 2020). Hence, the LRR region exhibits more variations than other regions of the gene.

The NBS-LRR proteins have very low steady state expression level. In the absence of pathogens, they remain in ADP-bound inactive state through intra-molecular interactions between their different domains or extramolecular interaction with another host protein (Meunier \& Broz 2017; Noman et al. 2019). These proteins are, however, induced in a timely manner when the pathogens come to interact with the plants. The interaction of plant NBS-LRR proteins and pathogen effectors has been extensively studied to understand the mechanism of plant and pathogen interaction. Generally, the NBS-LRR proteins directly or indirectly recognize effectors secreted by pathogens resulting in conformational changes of these proteins and exchange of ADP/ATP that causes activation of downstream signalling pathways leading to hypersensitive responses aimed to restrict the pathogen growth (Balint-Kurti 2019). Alternatively, the NBS-LRR proteins act as a guard by sensing and monitoring the status of other plant proteins targeted by pathogen effectors (Baggs et al. 2017). A classic example is the disease resistance protein RPMI in Arabidopsis thaliana where it detects the phosphorylation of RPM-1 Interacting Protein 4 (RIN4) triggered by the effectors AvrB and AvrRpm1 from Pseudomonas syringae pv. Glycinea and pv. Maculicola, respectively, and elicits the resistance response (Couto \& Zipfel 2016).

There is considerable evidence indicating the involvement and contribution of the NBS-LRR proteins in resistance response in many pathosystems. Expression of TIR-NBS-LRR-encoded grapevine gene VaRGA1 confers broad-spectrum resistance not only in grapevine but also in Arabidopsis and tobacco (Tian et al. 2020). Likewise, silencing of NBS-LRR gene SLNLC1 in a resistant Solanum lycopersicum cv. Motelle resulted in a susceptible phenotype (Cui et al. 2018).

Papaya (Carica papaya L.) is one of the important fruit crops in Malaysia planted for domestic and export markets. The main commercial variety grown in Malaysia is known as Eksotika which was developed by the Malaysian Agricultural Research and Development Institute (MARDI) three decades ago. The variety positioned the country as the second biggest contributor of world papaya (Sekeli et al. 2018). However, the production is severely affected by the outbreak of papaya dieback disease caused by Erwinia mallotivora (Mat Amin et al. 2011). The disease symptoms include greasy water-soaked lesions, spots on leaves and crowns defoliation and black spots of the papaya fruits. In an effort to keep the papaya industry afloat, a new hybrid variety called Viorica was developed by MARDI that is highly tolerant to dieback disease (Mohd Azhar et al. 2020). In order to elucidate the mechanism of tolerance in Viorica, a comparative transcriptomics was carried out between the Viorica and Eksotika in response to E. mallotivora (MARDI, unpublished data). Previously, genome data analysis has shown 54 NBS class R genes (Porter et al. 2009) and through the transcriptomic study, six NB-ARC transcripts were differentially expressed in response to the treatment. However, the involvement of papaya NB-ARC genes in response to dieback disease has never been validated. In the present study, bioinformatic analysis and expression profiling of NB-ARC candidate genes in two papaya varieties were carried out to obtain a clearer understanding of the involvement of the genes during interaction with $E$. mallotivora.

\section{MATERIALS AND METHODS}

\section{PLANT MATERIAL AND INOCULATION}

Carica papaya cv. Eksotika (susceptible, S) and Viorica (tolerant, T) seeds were germinated in a soil mixture consisting of topsoil, sand and poultry manure with a ratio of $3: 2: 1$, respectively. After three weeks of germination, the seeds were transferred to 12 " $\times 12$ " polybags and grown in a glasshouse under a controlled environment with a temperature range between $28^{\circ} \mathrm{C}$ and $30{ }^{\circ} \mathrm{C}$ until it reached three months old. E. mallotivora strain BTMARDI inoculum was prepared in Luria-Bertani media 
broth for $40 \mathrm{~h}$ at $28^{\circ} \mathrm{C}$ with agitation of $150 \mathrm{rpm}$. The main vein of fully expanded papaya leaves was inoculated using a sterile needle containing E. mallotivora culture at a concentration of $10^{6}$ colony forming unit (CFU) (Supian et al. 2017). Control plants were treated similarly but with sterile water. The leaves were then harvested at 0 , 24, and $48 \mathrm{~h}$ post-inoculation (hpi) before the onset of disease symptom.

\section{IDENTIFICATION OF PUTATIVE PATHOGEN-RESPONSIVE NB-ARC TRANSCRIPTS FROM PAPAYA TRANSCRIPTOME DATABASE AND SEQUENCE ANALYSIS}

The annotated $C$. papaya transcriptome database (available upon request to MARDI) were screened for NB-ARC transcripts that contained Pfam NB (NBARC) family (PF00931) domain with e-value cut off at 1.0, similar to the threshold set by Porter et al. (2009). Different transcript sequences that mapped to a single protein were removed. Candidate NB-ARC sequences with significant value of expression in Eksotika-S and/ or Viorica-T (fold change more than 2.0) were selected. The transcript sequences were translated into proteins using ExPASy translate tool (https://web.expasy.org/ translate/). Identification of open reading frame (ORF) in the translated protein sequences was done using an ORF finder (http://www.ncbi.nlm.nih.gov/projects/gorf/). The ORFs were aligned using the NCBI database BlastP to search for homologous sequences. Protein sequence hits with the highest similarity score were selected and further analyzed using the online software SMART (http://smart. embl-heidelberg/), NCBI CDD (https:/www.ncbi.nlm.nih. gov/Structure/bwrpsb/bwrpsb.cgi) and MOTIF (https:// www.genome.jp/tools/motif/) to check for the domains. Annotation of predicted transmembrane regions was done using TMHMM Server v.2.0 (http://www.cbs.dtu.dk/ services/TMHMM/) and coiled-coil motifs were predicted by the COILS program (Lupas et al. 1991) and HMMER (https://www.ebi.ac.uk/Tools/hmmer/).

\section{PHYLOGENETIC TREE CONSTRUCTION}

The predicted amino acid sequences of candidate NBARC proteins from C. papaya together with well-studied resistance proteins in other plant species were aligned using ClustalW in Mega X (Kumar et al. 2018). The alignment was used for the construction of a phylogenetic tree using Maximum Likelihood (ML) method in MEGA $\mathrm{X}$ with a bootstrap value of 500 to validate the tree topology.

ISOLATION OF TRANSCRIPT AND PROTEIN STRUCTURE

\section{ANALYSIS}

Transcript 4993 of CpNBS1 was amplified from both Eksotika-S and Viorica-T and aligned using BioEdit program version 7.2.6 (Hall 1999). The position of LRR domains in the transcript was confirmed using NCBI CDD. The 3D structure and function of the proteins were predicted by an online server, I-TASSER (Zhang et al. 2016) using default parameters where all templates were included to maintain the quality of the I-TASSER modeling.

\section{EXPRESSION PROFILING OF NB-ARC TRANSCRIPTS IN $C$. papaya CHALLENGED WITH E. mallotivora}

Total RNA was extracted from the inoculated and control leaves of both Eksotika-S and Viorica-T by using RNeasy Plant Mini kit (Qiagen, Germany) according to the manufacturer's instructions. RNase-free DNase Set (Qiagen, Germany) was used to remove genomic DNA contamination. The integrity of RNA samples was examined through agarose gel electrophoresis and NanoDrop 1000 Spectrophotometer (Thermo Scientific, USA). Then, cDNA was prepared from $2 \mu \mathrm{g}$ RNA using iScript Reverse Transcription Supermix (BioRad, USA). The expression level of NB-ARC transcripts was determined by semi-quantitative RT-PCR using the eukaryotic initiation factor 4A $(E I F)$ gene (Genbank ID: FJ644949.1) as the internal reference. Primer pairs used to amplify all the transcripts were listed in Table 1. A total volume of $25 \mu \mathrm{L}$ was prepared consisting of $1 \mu \mathrm{L}$ cDNA, $2 \times$ MyTaq Red Mix ${ }^{\mathrm{TM}}$ DNA Polymerase (Bioline), $1 \mu \mathrm{M}$ forward primer, $1 \mu \mathrm{M}$ reverse primer and sterile water. PCR reaction was carried out as follows: pre-denaturation at 94 ${ }^{\circ} \mathrm{C}$ for $1 \mathrm{~min}, 27$ cycles of denaturation at $94{ }^{\circ} \mathrm{C}$ for $30 \mathrm{~s}$, annealing for $30 \mathrm{~s}$, and extension at $72{ }^{\circ} \mathrm{C}$ for $30 \mathrm{~s}$. Final elongation was carried out at $72{ }^{\circ} \mathrm{C}$ for $10 \mathrm{~min}$.

\section{RESULTS AND DISCUSSION}

Plant disease resistance is well-known to be mediated largely by NBS-LRR proteins. The NBS-LRR domains residing in these proteins are essential for the recognition of pathogen effectors in order to activate defense signalling that eventually confer disease resistance in a plant (Lozano et al. 2015). In the present study, three ORFs with NB-ARC or AAA domain that showed the highest expression value were identified from the translated transcriptomic database of Eksotika-S and Viorica-T that have been challenged with E. mallotivora. The selected proteins were then named CpNBS1, CpNBS2 
and CpNBS3 (Table 2). According to the BlastP analysis, all three sequences were highly homologous to protein from $C$. papaya. Interestingly, $C p N B S 1$ gene produced three truncated transcripts that matched the same protein in which two of them (transcript 4993 and 4756) are identical. No full-length CpNBS1 transcript was detected in the E. mallotivora-infected C. papaya transcriptome. The putative RGA3 protein (CpNBS1) also present high sequence identity with putative protein CpRGA1 and its isoforms X1, X2, and X3 (\% query cover: 99, 98, 98, 92; \% identity: $76,83,83, \& 81$, respectively). It is common for $\mathrm{R}$ gene transcripts to be produced in isoforms that contain only one or two domains from the full-length transcripts (Marone et al. 2013; Monteiro \& Nishimura 2018). Such alternative transcripts were reported to remain stable and encode truncated proteins that contribute to successful immunity in certain cases of NBS-LRR expression control (He et al. 2018; Lai \& Eulgem 2017). It is assumed that these truncated proteins gain their positive role by alleviating self-inhibition of the full-length proteins or by functioning as adaptors in the signal transduction pathway (Baggs et al. 2017). A previous study showed that a single domain of $P i$-ta, a dominant blast-resistance gene in $O$. sativa called the TRX was sufficient to deliver the highest level of expression compared to full length or other truncated transcripts in a resistant rice variety (Costanzo \& Jia 2009).

Genome analysis of $C$. papaya recorded the lowest number of NBS R genes (54), compared to A. thaliana (174), O. sativa (519) and Vitis vinifera (535) (Porter et al. 2009), which might explain the small number of $C$. papaya NBS genes that were responsive to E. malllotivora infection.

NBS-LRR proteins are assumed to be cytoplasmic since most of them lack signal peptide or transmembrane domain (Boyes et al. 1998; McHale et al. 2006). Based on the prediction using TMHMM server 2.0 and PSORT software, all the CpNBS proteins are lack of transmembrane region and were located in the cytoplasm. Analysis of conserved domains of the matched protein sequences from NCBI database showed the presence of NB-ARC or AAA domains (Figure 1). Only CpNBS1 contained NB-ARC domain while CpNBS2 and 3 contained AAA domain. According to the information available on the Pfam database (https://pfam.xfam.org/), both NB-ARC and AAA belong to the AAA family proteins under the P-loop_NTPase (CL0023) clan which often function as sensor and response factor. Hence, depending on the search criteria, protein sequences with either domain may or may not be included in the search result as potential disease resistance gene homolog (RGH). A similar case was reported where varying numbers of RGH from the same plant variety were identified in different studies using different search criteria (Sharma et al. 2017).

As the only pathogen-responsive NB-ARC proteins identified in this study, CpNBS1 belongs to the CC-NBSLRR group of RGH based on the presence of coiled-coil domain at the $\mathrm{N}$ terminus and LRR domain at the $\mathrm{C}$ terminus (Figure 1). Based on the report by Porter et al. (2009), only six of the 54 NBS genes identified in $C$. papaya were predicted to encode CC motifs, and only four of those genes contain an LRR domain. One ORF in the study, 16.137 was predicted to encode two NBS domains, similar to CpNBS1. However, no sequence information provided by Porter et al. (2009) hindering direct sequence comparison between the two proteins. Transcripts 4993 and 4756 encode for the LRR domain while transcript 4221 does not specifically encode for any domain. The LRR domain with its slender conformation, is considered unique since it can maximizes surface area for proteinprotein interaction and tolerate high levels of variability, making it an indispensable player in plant defence. NBSLRR genes are known to undergo alternative splicing and the presence of alternative transcripts encoding receptors with an absent or truncated LRR domain is an interesting feature of certain members of the class (Padmanabhan et al. 2009). However, there has been no report of the presence of alternative transcript encoding LRR domain alone in response to pathogen infection as observed in this study. To date, ambiguities persist about the mechanistic role of LRR (Noman et al. 2019). Hence, the finding in this study could add a new link in signalling networks for plant innate immunity.

To examine the phylogenetic and evolutionary relationship of NB-ARC proteins from C. papaya and other plant species, a phylogenetic tree was constructed which include A. thaliana, Solanum lycopersicum (tomato), $O$. sativa (rice), Nicotiana tabacum (tobacco), Zea mays (corn), Glycine max (soybean), Solanum tuberosum (potato), Malus domestica (apple), and Prunus persica (peach). It was observed from the phylogenetic tree that CpNBS1 was closely related with CC-NBS-LRR protein I-2 (immunity to race 2) from $S$. lycopersicum and $N$. tabacum while CpNBS2 and CpNBS3 were grouped together with the majority of $\mathrm{R}$ genes from Arabidopsis (Figure 2). I-2 protein belongs to the Type I R-genes, which had frequent sequence exchanges among its homologues in the different genotypes of the same species (Wei et al. 
2014). As a result, a particular plant species may harbor various sets of chimeric R-genes. However, extensive sequence analysis has to be conducted to make a plausible conclusion about CpNBS1.

To confirm the involvement of pathogen-responsive CpNBS transcripts to E. mallotivora infection, the transcripts were assayed for their expression patterns in a challenge experiment. The $C$. papaya Eksotika-S and Viorica- $T$ exhibited different disease responses after exposure to dieback pathogen, E. mallotivora. Eksotika-S is highly susceptible whereas Viorica-T is tolerant (Mohd Azhar et al. 2020). Both Ekotika-S and Viorica-T were inoculated with E. mallotivora and leaf sample was collected at 0,24 , and 48 hpi before the onset of disease symptoms for semi-quantitative PCR. The NBSLRR genes are finely regulated to ensure the correct dose of immune responses while limiting any detrimental effects on plant growth. Hence, they are basally expressed in plant tissues and only up-regulated upon pathogen detection to initiate defence responses (Lai \& Eulgem 2017; Marone et al. 2013; Zhang et al. 2016).

Based on Figure 3, all transcripts were basally expressed in both tolerant and susceptible varieties of $C$. papaya. Transcript 4993 of CpNBS1 was upregulated at 48 hpi in the susceptible plant in response to E. mallotivora whereas in the tolerant plant, it was downregulated. It seems like the reduced level of the transcript is favorable for $C$. papaya when under attack by E. mallotivora. Both transcript 3009 and 4999 seemed to respond to wounding based on the up-regulated and down-regulated expressions in the control sample of Eksotika-S and Viorica-T, respectively. It is not uncommon for woundresponsive gene to encode proteins involved in cellular responses to biotic stress since both factors share a number of components in their signalling pathways (Cheong et al. 2002). In response to E. mallotivora, the expression was slightly downregulated at $48 \mathrm{hpi}$ in Eksotika-S but upregulated at 24 hpi in Viorica-T, which is opposite to the transcript 4993 of $C p N B S 1$. In contrast, transcript 2792 of $C P N B S 3$ was stably expressed in both susceptible and tolerant $C$. papaya. Transcript of many $\mathrm{R}$ genes are known to accumulate transiently in a localized response to pathogen infection and plant defence response is a result of a complex interplay between many proteins and metabolites at different time points (Dang et al. 2019; Goyal et al. 2020; Lai \& Eulgem 2017). At this stage, it is possible that the negative regulation of the transcript 4993 of $C P N B S 1$ and positive regulation of the transcript 3009 of $C p N B S 2$ genes give rise to the tolerant phenotype of Viorica to E. mallotivora infection. Functional characterization of the truncated transcripts in comparison to the full length would shed more knowledge on their exact role during C. papaya-E. mallotivora interaction.

Based on the sequence analysis and expression profiling, transcript 4993 of CPNBS1 was selected for further analysis. The transcript sequences were amplified from both Eksotika-S and Viorica-T with the size of 1398 bp. Alignment of the two sequences showed five nucleotide variations at positions 404, 921, 958, 968, and 1041 where nucleotide $\mathrm{A}$ in 4993-Eksotika changed to $\mathrm{G}$ in 4993-Viorica at all these positions (Figure 4). These nucleotide variations led to differences at three amino acid positions in the translated sequences between the two varieties at position 135 (lysine to arginine), 320 (methionine to valine), and 323 (asparagine to serine) (Figure 5). Interestingly, amino acid variation at position 135 (lysine to arginine) lies in the conserved LRR domain. Even though both arginine and lysine are positively charged polar amino acids (Strickler et al. 2006), the protein function may be affected by the substitution of lysine to arginine owing to the geometric structure of arginine which provides more stability to the protein structure (Sokalingam et al. 2012).

To gain more information on the structure-function of the LRR domain in susceptible and tolerant $C$. papaya, a three-dimensional structure (3D) of the domain was predicted using comparative modelling approach. The structure of the translated protein sequences was predicted using the tertiary structure of LRR receptor-like serine/ threonine- protein kinase FLS2 from Arabidopsis (PDB ID: $4 \mathrm{mn} 8$ ) as a template with $95 \%$ sequence coverage and $28 \%$ similarity. Secondary structures of protein like $\alpha$-helix and $\beta$-sheets play an important role in the folding of a protein where $\alpha$-helix is more favourable for the stability and organization of a protein (Deller et al. 2016; Stanger et al. 2001). Based on the 3D structures in Figure 6, 4993-Viorica is composed of $17 \beta$-sheets and $15 \alpha$-helixes (Figure 6(A)) while 4993-Eksotika contains $19 \beta$-sheets and $13 \alpha$-helixes (Figure 6(B)) suggesting that the former is more stable.

In addition, there is a remarkable difference in the amino acid residues involved in the ligand binding surface of 4993-Viorica with only seven amino acid residues (aspartate, serine, asparagine, cysteine, tyrosine, leucine, and glutamate at positions 150, 152, 174, 176, 198, 200, 222, respectively) (Figure 7(A)) in comparison to 15 amino acid residues (serine, threonine, glutamate, serine, aspartate, isoleucine, asparagine, histidine, 
tyrosine, leucine, threonine, glutamate, valine, histidine, and arginine at position 73, 95, 96, 124, 150, 172, 174, 196, 198, 200, 220, 222, 225, 252, \& 254, respectively) in 4993-Eksotika (Figure 7(B)). Similar proteins with different amino acid residues involved in ligand binding are expected to bind different types of ligand (Lee et al. 2017). This is because the amino acids at ligand binding surface will be arranged in a specific conformation that allows them to interact with a ligand that fit the conformation perfectly, similar to the lock-and-key concept in enzyme-substrate interactions. The observed difference between the LRR domain of 4993-Eksotika and 4993-Viorica suggests that the LRR domain may determine the specificity of recognition of $E$. mallotivora effector. In a recent study involving $P v r 4$ disease-resistance gene of pepper, LRR domain swapping between the susceptible and resistant Pvr4 allele showed that the LRR domains of the resistant allele are important for the recognition of avirulence protein NIb from Peper mottle virus (Kim et al. 2018). Both alleles contain an identical NB-ARC domain but a relatively different LRR domain.

TABLE 1. Primers used in this study

\begin{tabular}{|c|c|c|c|}
\hline Transcript ID/Gene name & Forward & Reverse & $\begin{array}{c}\text { Annealing } \\
\text { temperature }\left({ }^{\circ} \mathrm{C}\right)\end{array}$ \\
\hline \multicolumn{4}{|l|}{ RT-PCR } \\
\hline $\begin{array}{c}\text { Ref_Papaya_- } \\
\text { Transcript_16838_4993 }\end{array}$ & ACATTTGAATGCTTGGTGGTGG & AGTGGAGGCAACTGCTCAAT & 58 \\
\hline $\begin{array}{c}\text { Ref_Papaya_- } \\
\text { Transcript_39327_3009 }\end{array}$ & CCGGATACCATGGAGAAGCT & CGTAGCCAACCTCATCCAGT & 56 \\
\hline $\begin{array}{c}\text { Ref_Papaya_ } \\
\text { Transcript_38330_2792 }\end{array}$ & GTTCTGGGTTTCTTCCAAAACCA & AGGCTTCCTCCCCAAATCTA & 57 \\
\hline EIF & GGGAAGACGCCA GGTGTA & GCTTGGATTTGGCAGAGAAG & 58 \\
\hline \multicolumn{4}{|l|}{ Transcript isolation } \\
\hline $\begin{array}{l}\text { Ref_Papaya_- } \\
\text { Transcript } 16838 \quad 4993\end{array}$ & CCCGGGATGGAAAAAGGTGAGTTGTACTTT & CTCGAGTCACCAAACTTTAAAATGCCAG & 55 \\
\hline
\end{tabular}

TABLE 2. List of pathogen-responsive LRR proteins identified in current study

\begin{tabular}{|c|c|c|c|}
\hline Transcript ID & Gene name & ORF length & $\begin{array}{c}\text { Blast results (\% query cover, E value, identities, accession } \\
\text { no., description, [species]) }\end{array}$ \\
\hline $\begin{array}{l}\text { Ref_Papaya_- } \\
\text { Transcript_16838_4993 } \\
\text { Ref_Papaya_- } \\
\text { Transcript_16838_4756 } \\
\text { Ref_Papaya_- } \\
\text { Transcript_16835_4221 }\end{array}$ & $C p N B S 1$ & $\begin{array}{l}474 \\
297\end{array}$ & $\begin{array}{l}\text { 100, 0.0, 100, XP_0121904876.1, putative disease resistance } \\
\text { protein RGA3 [Carica papaya] } \\
\text { 100,0.0, XP_0121904876.1, putative disease resistance } \\
\text { protein RGA3 [Carica papaya] } \\
\text { 95, 0.0, 100, XP_0121904876.1, putative disease resistance } \\
\text { protein RGA3 [Carica papaya] }\end{array}$ \\
\hline $\begin{array}{c}\text { Ref_Papaya_-_ } \\
\text { Transcript_39327_3009 }\end{array}$ & CpNBS2 & 537 & $\begin{array}{l}\text { 100, 0.0, 99.07, XP_021897305.1, cell division cycle protein } \\
48 \text { homolog }[\text { Carica papaya }]\end{array}$ \\
\hline $\begin{array}{l}\text { Ref_Papaya_- } \\
\text { Transcript_38330_2792 }\end{array}$ & $C p N B S 3$ & 685 & $\begin{array}{l}\text { 100, 0.0, 100, XP_021897864.1, uncharacterized protein } \\
\text { ycf } 45[\text { Carica papaya }]\end{array}$ \\
\hline
\end{tabular}


CpNBS1

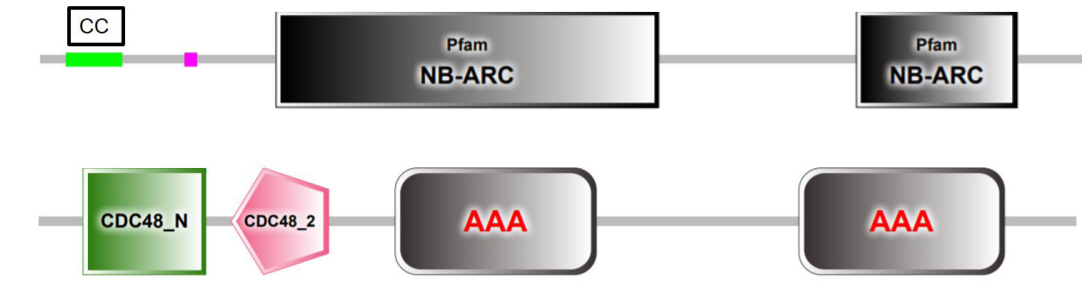

CpNBS2

CpNBS3

AAA

FIGURE 1. Domain structure of CpNBS1, CpNBS2 and CpNBS3 proteins analysed using SMART.

Only confidently predicted domains, repeats, motifs and features are shown. Purple box

indicates a low complexity region

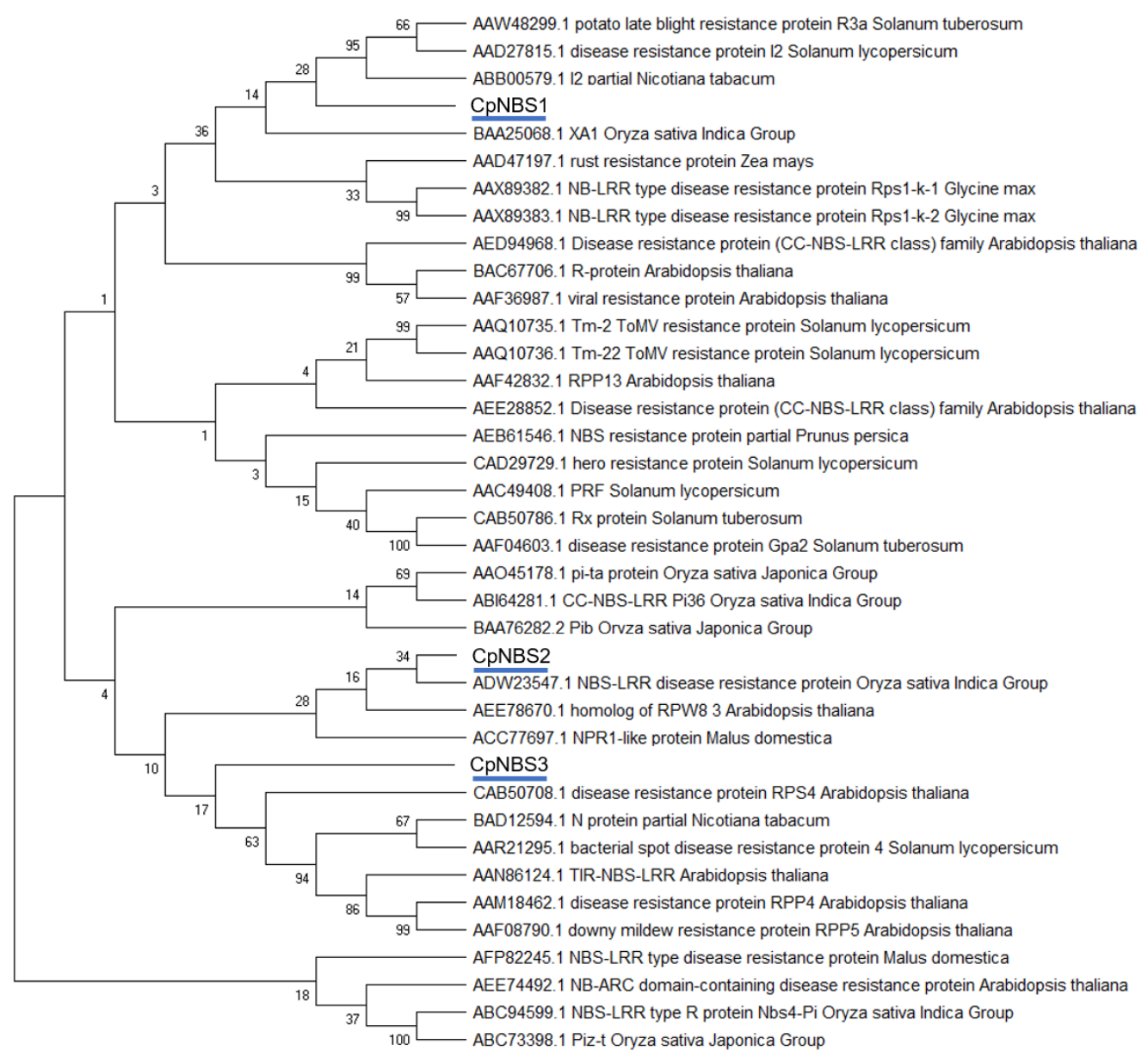

FIGURE 2. Phylogenetic tree showing relationships of LRR proteins between C. papaya and wellstudied resistance proteins in other plant species. The LRR proteins from C. papaya identified in this study were denoted with a blue underline. The unrooted phylogenetic tree was constructed with the maximum likelihood (ML) tree. Tree reliability was assessed using 500 bootstrap replicates. Bootstrap percentages are indicated at branches 
Eksotika (Susceptible)

Viorica (Tolerant)

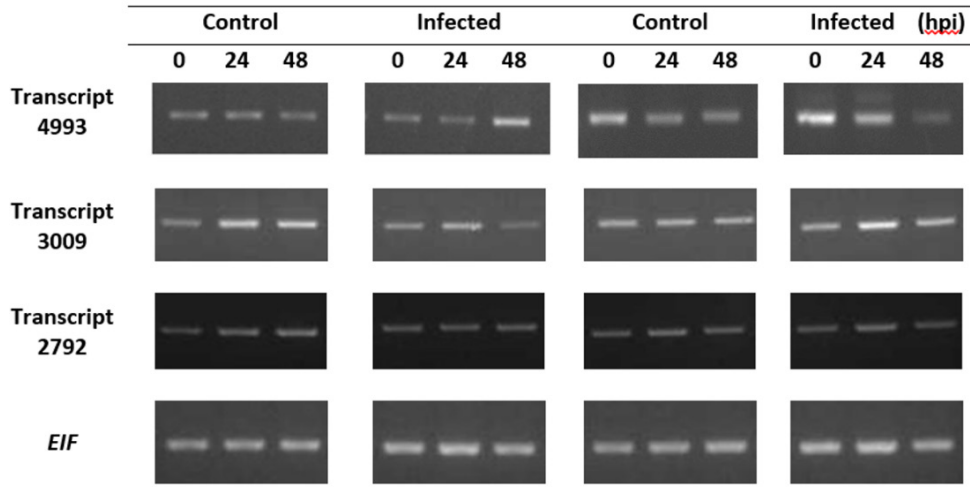

FIGURE 3. Modulation of NBS-LRR transcripts expression by E. mallotivora in C. papaya cv. Viorica and Eksotika. The semi-quantitative expression was recorded at 0,24 , and $48 \mathrm{~h}$ post-inoculation (hpi) with E. mallotivora.

Eukaryotic initiation factor $4 \alpha(E I F)$ was used as the internal reference gene

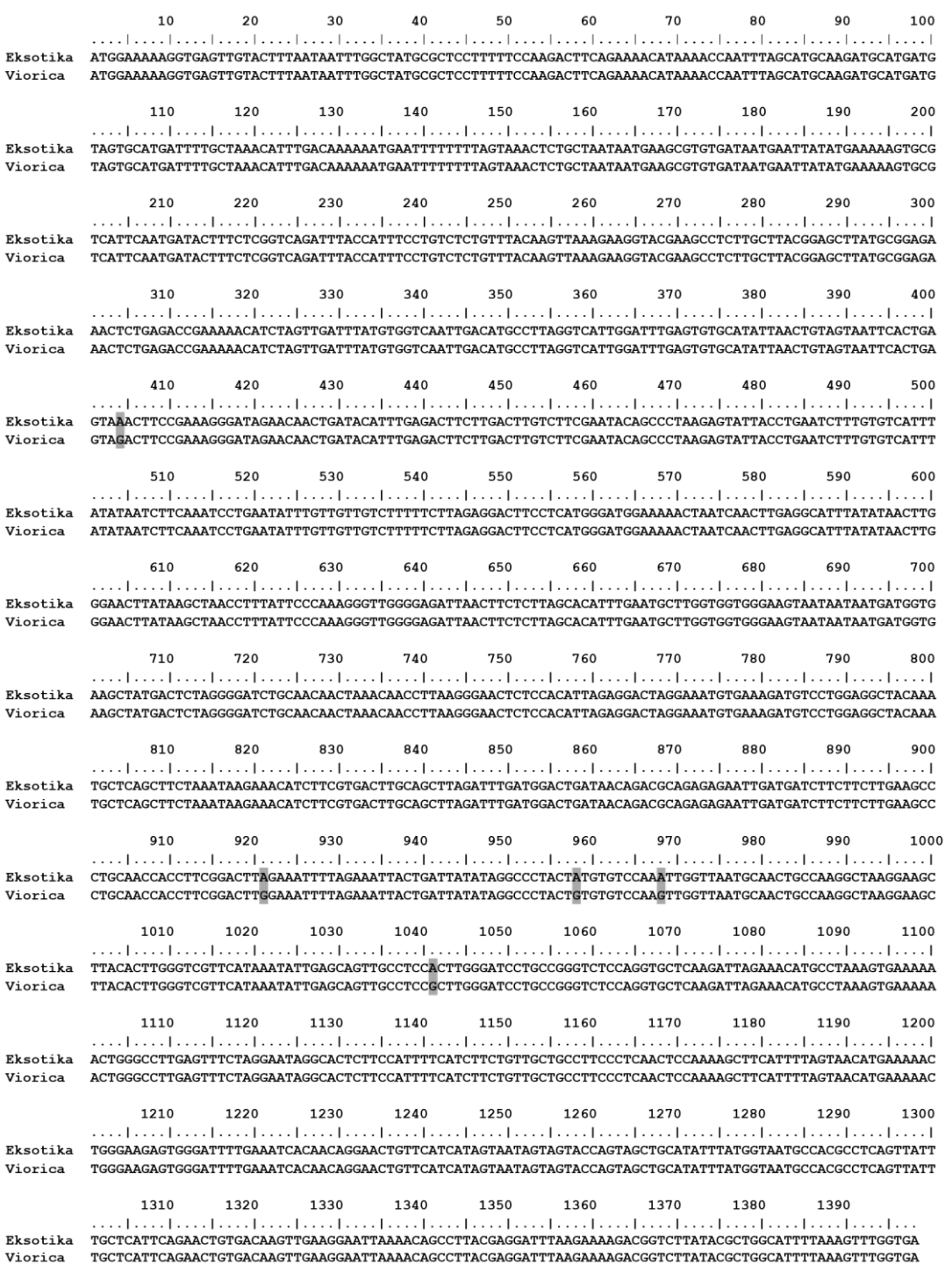

FIGURE 4. Nucleotide sequence alignment of transcript 4993 isolated from $C$. papaya cv. Eksotika and Viorica. Nucleotide variations at positions 404, 921, 958, 968 , and 1041 are indicated by grey-shaded letters 


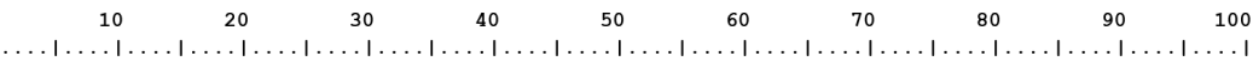
MEKGELYFNNLAMRSFFQDFRKHKTNLACKMHDVVHDFAKHLTKNEFFLVNSANNEACDNELYEKVRHSMILSRSDLPFPVSVYKLKKVRSLLLTELMRR $\begin{array}{ll}\text { Eksotika } & \text { MEKGELFN } \\ \text { Viorica } & \text { MEKGELYFNNLAMRSFFQDFRKHKTNLACKMHDVVHDFAKHLTKNEFFLVNSANNEACDNELYEKVRHSMILSRSDLPFPVSVYKLKKVRSLLLTELMRR }\end{array}$

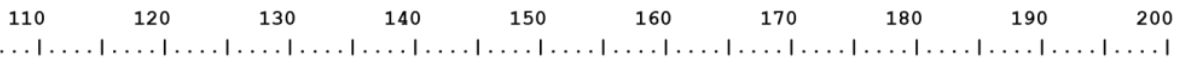

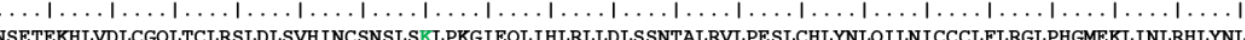
Eksotika NSETEKHLVDLCGQLTCLRSLDLSVHINCSNSLSKLPKGIEQLIHLRLLDLSSNTALRVLPESLCHLYNLQILNICCCLFLRGLPHGMEKLINLRHLYNL Viorica NSETEKHLVDLCGQLTCLRSLDLSVHINCSNSLSRLPKGIEQLIHLRLLDLSSNTALRVLPESLCHLYNLQI LNICCCLFLRGLPHGMEKLINLRHLYNL

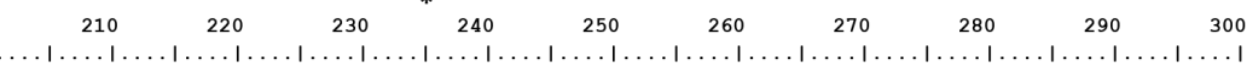
GTYKLTF I PKGLGRLTSLSTFECLVVGSNNNDGEAMTLGDLQQLNNLKGTLH IRGLGNVKDVLEATNAQLLNKKHLRDLQLRFDGLI TDAERIDDLLLEA TYKLTFIPKGLGRLTSLSTFECLVVGSNNNDGEAMTLGDLQQLNNLKGTLH IRGLGNVKDVLEATNAQLLNKKHLRDLQLRFDGLITDAERIDDLLLEA

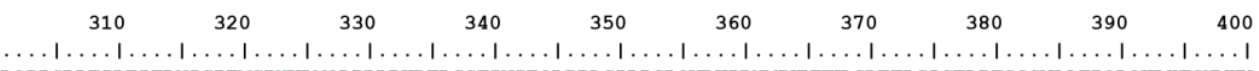
LQPPSDLE I LE I TDY I GPTMCPNWLMQLPRLRKLTLGSF INIEQLPPLGI LPGLQVLKIRNMPKVKKLGLEFLG I GTLPFSSSVAAFPQLQKLHFSNMKN $\begin{array}{ll}\text { Eksotika } & \text { LQPPSDLEILEI TDYIGPTMCPNWLMQLPRLRKLTLGSF INIEQLPPLGILPGLQVLKI RNMPKVKKLGLEFLGIGTLPFSSSVAAFPQLQKLHFSNMKN } \\ \text { Viorica } & \text { LQPPSDLEILEI TDYIGPTVCPSWLMQLPRLRKLTLGSF INIEQLPPLGILPGLQVLKIRNMPKVKKLGLEFLGIGTLPFSSSVAAFPQLQKLHFSNMKN }\end{array}$

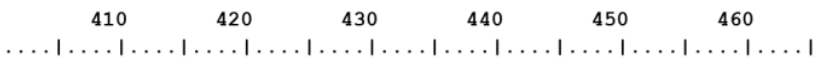

Eksotika WEEWDFE ITTGTVHHSNSSTSSCIFMVMPRLSYLLIQNCDKLKELKQPYEDLRKDGLIRWHFKVW

Viorica WEEWDFEITTGTVHHSNSSTSSCIEMVMPRLSYLLIONCDKLKELKOPYEDLRKDGLIRWHFKVW

FIGURE 5. Amino acid sequence alignment of 4993 translated sequence from C. papaya

cv. Eksotika and Viorica. Conserved LRR domains are underlined in red. Amino acid variations at positions 135, 320, and 323 are indicated by an asterisk and coloured letters
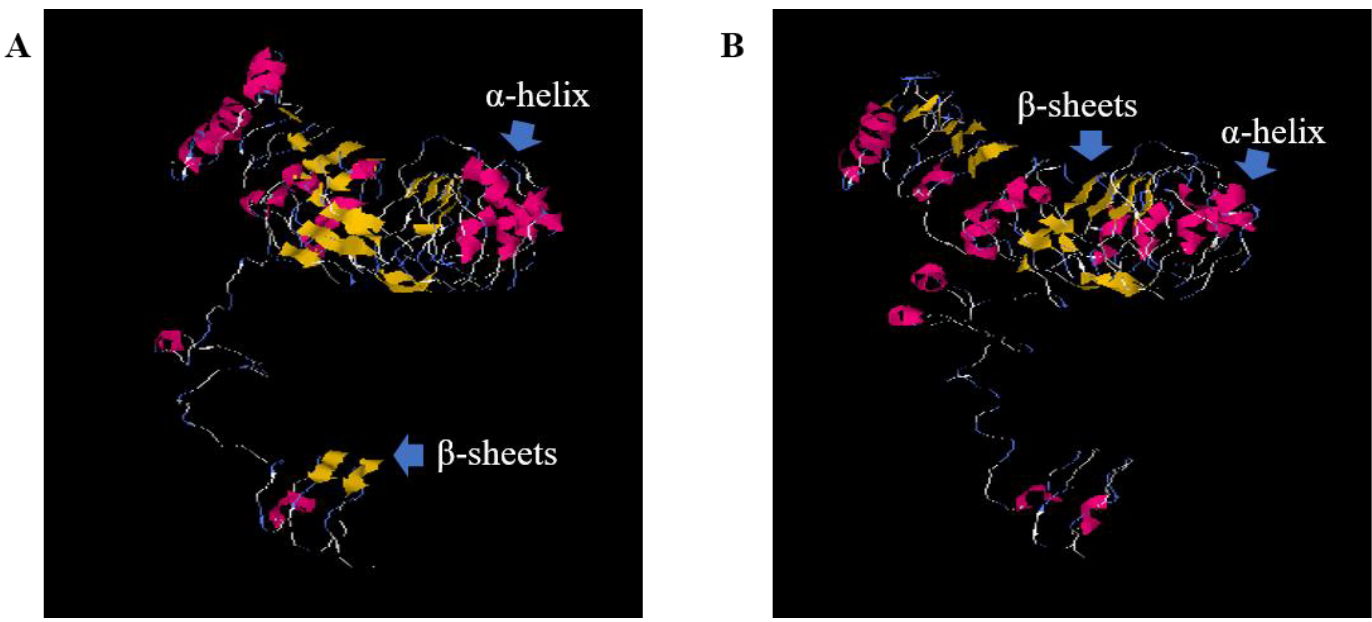

FIGURE 6. The molecular modelling of 4993 translated sequence using I-TASSER software. A) Structural 3D model of 4993 translated sequence from C. papaya cv. Viorica with a TM score of $0.67+-0.13$ and Cs of -1.14 and B) Structural 3D model of 4993 translated sequence from C. papaya cv. Eksotika with a TM score of $0.68+-$ 0.12 and Cs of -0.25 . Secondary structure features, $\beta$-sheets (yellow) and $\alpha$-helix (pink) are indicated by a blue arrow 
A

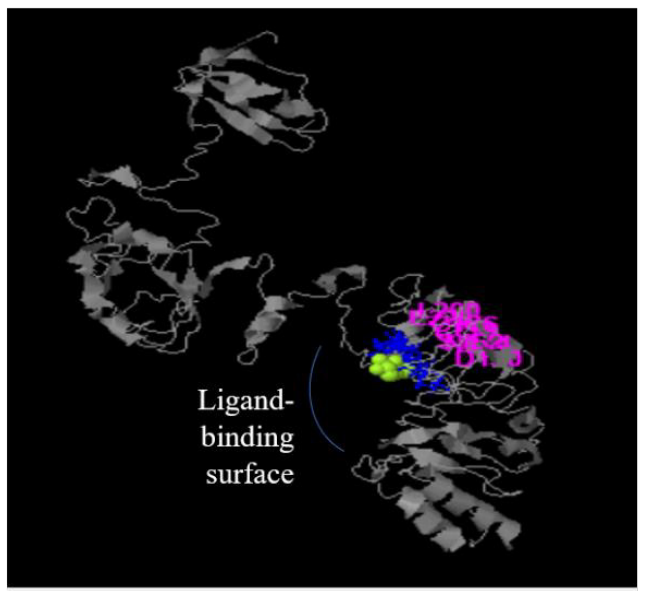

B

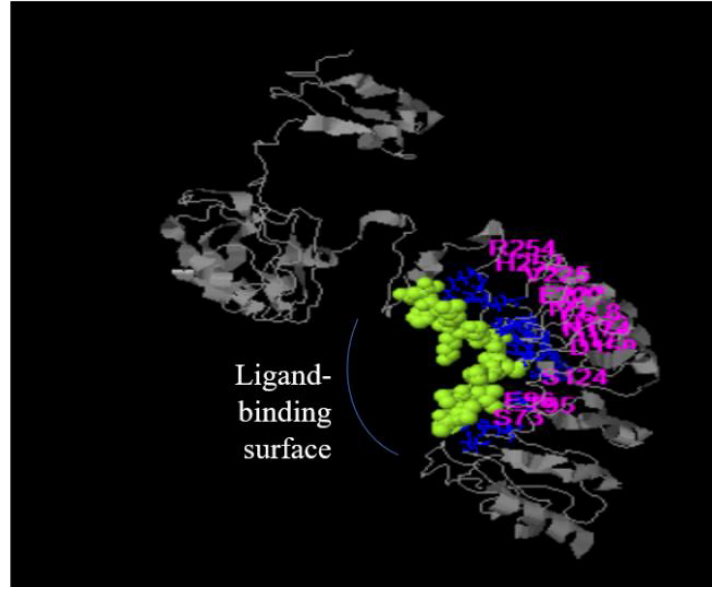

FIGURE 7. Predicted amino acid residues involved in the ligand binding surface of 4993 translated sequence. A) Ligand binding surface of 4993 translated sequence from $C$. papaya $\mathrm{cv}$. Viorica and B) Ligand binding surface of 4993 translated sequence from $C$. papaya $\mathrm{cv}$. Eksotika. The amino acid residues involved are denoted in purple

\section{CONCLUSION}

In the present study, LRR-encoding transcripts (4993, 4756, and 4221) were identified in C. papaya translated transcriptome database of Eksotika (susceptible) and Viorica (tolerant) in response to bacterial pathogen $E$. mallotivora. The matching C. papaya proteins were named CpNBS1, CpNBS2, and CpNBS3, respectively. Despite truncated, two of the identified transcripts, 4993 and 4756 were identical and encode a complete LRR domain. CpNBS1 which is annotated as resistance gene analog 3 (RGA3) is of particular interest since it belongs to the CC-NBS-LRR class of the R gene. Semi-quantitative PCR showed that transcripts 4993 and 4576 were differentially expressed in response to $E$. mallotivora. Structural analysis of the 4993-Eksotika and 4993-Viorica translated proteins showed striking differences in the number of $\beta$-sheets and $\alpha$-helixes as well their ligand-binding surface, suggesting the role of the LRR domain in determining the specificity of recognition of E. mallotivora effector. Overall, this study provides new insight into the role of NBS-LRR gene in papaya that could have implications in enhancing of plant disease resistance through genetic engineering.

\section{ACKNOWLEDGEMENTS}

This research was supported by the Ministry of Higher Education (MOHE), Malaysia under Fundamental Research Grant Scheme (FRGS/1/2016/STG05/MOA/02/1) and Universiti Putra Malaysia (GP-IPS/2018/9623300). We thank Dr. Adrain Ling Chieng Kuang for providing the transcripts data and Dr. Johari Sarip for supplying the plant materials and Dr Nur Fatihah Mohd Yusoff for the advice on bioinformatic analysis.

\section{REFERENCES}

Baggs, E., Dagdas, G. \& Krasileva, K.V. 2017. NLR diversity, helpers and integrated domains: Making sense of the NLR identity. Current Opinion in Plant Biology 38: 59-67.

Balint-Kurti, P. 2019. The plant hypersensitive response: Concepts, control and consequences. Molecular Plant Pathology 20: 1163-1178.

Bayless, A.M. \& Nishimura, M.T. 2020. Enzymatic functions for Toll/Interleukin-1 receptor domain proteins in the plant immune system. Frontiers in Genetics 11: 539.

Boyes, D.C., Nam, J. \& Dangl, J.L. 1998. The Arabidopsis thaliana RPM1 disease resistance gene product is a peripheral plasma membrane protein that is degraded coincident with the hypersensitive response. Proceedings of National Academy of Sciences USA 95: 15849-15854. 
Cheong, Y.H., Chang, H-S., Gupta, R., Wang, X., Zhu, T. \& Luan, S. 2002. Transcriptional profiling reveals novel interactions between wounding, pathogen, abiotic stress, and hormonal responses in Arabidopsis. Plant Physiol. 129: 661-677.

Costanzo, S. \& Jia, Y. 2009. Alternatively spliced transcripts of Pi-ta blast resistance gene in Oryza sativa. Plant Science 177: 468-478.

Couto, D. \& Zipfel, C. 2016. Regulation of pattern recognition receptor signaling in plants. Nature Reviews Immunology 16: $537-522$

Cui, Y., Jiang, J., Yang, H., Zhao, T., Xu, X. \& Li, J. 2018. Virus-induced gene silencing (VIGS) of the NBS-LRR gene SLNLC1 compromises Sm-mediated disease resistance to Stemphylium lycopersici in tomato. Biochemical and Biophysical Research Communications 503: 1524-1529.

Deller, M.C., Kong, L. \& Rupp, B. 2016. Protein stability: A crystallographer's perspective. Acta Crystallographica Section F, Structural Biology Communications 72(Part 2): 72-95.

Dang, P.M., Lamb, M.C., Bowen, K.L. \& Chen, C.Y. 2019. Identification of expressed R-genes associated with leaf spot diseases in cultivated peanut. Molecular Biology Reports 46: 225-239.

Goyal, N., Bhatia, G., Sharma, S., Garewal, N., Upadhyay, A., Upadhyay, S.K. \& Singh, K. 2020. Genome-wide characterization revealed role of NBS-LRR genes during powdery mildew infection in Vitis vinifera. Genomics 112(1): 312-322

Hall, T.A. 1999. BioEdit: A user-friendly biological sequence alignment editor and analysis program for Windows 95/98/ NT. Nucl. Acids. Symp. Ser. 41: 95-98.

He, S.L., Jiang, J.Z., Chen, B.H., Kuo, C.K. \& Ho, S.L. 2018. Overexpression of a constitutively active truncated form of OsCDPK1 confers disease resistance by affecting OsPR10a expression in rice. Scientific Reports 8: 403.

Kim, S.B., Lee, H.Y., Choi, E.H., Park, E., Kim, J.H., Moon, K.B., Kim, H.S. \& Choi, D. 2018. The coiled-coil and leucine-rich repeat domain of the potyvirus resistance protein $P v r 4$ has a distinct role in signaling and pathogen recognition. Molecular Plant-Microbe Interactions 31(9): 906-913.

Kumar, S., Stecher, G., Li, M., Knyaz, C. \& Tamura, K. 2018. MEGA X: Molecular evolutionary genetics analysis across computing platforms. Molecular Biology and Evolution 35: $1547-1549$

Lai, Y. \& Eulgem, T. 2017. Transcript-level expression control of plant NLR genes. Molecular Plant Pathology 19(5): 1267-1281.

Lee, J., Konc, J., Janežič, D. \& Brook, B.R. 2017. Global organization of a binding site network gives insight into evolution and structure-function relationships of proteins. Scientific Reports 7: 11652
Lozano, R., Hamblin, M.T., Prochnik, S. \& Jannick, J.L. 2015. Identification and distribution of the NBS-LRR gene family in the cassava genome. BMC Genomics 16(360): 1-14.

Lupas, A., Van Dyke, M. \& Stock, J. 1991. Predicting coiled coils from protein sequences. Science 252: 1162-1164.

Marone, D., Russo, M.A., laido, G., DeLeonardis, A.M. \& Mastrangelo, A.M. 2013. Plant nucleotide binding siteleucine-rich repeat (NBS-LRR) genes: Active guardians in host defense responses. International Journal of Molecular Sciences 14: 7302-7326.

Mat Amin, N., Bunawan, H., Redzuan, R.A. \& Jaganath, I.B.S 2011. Erwinia mallotivora sp., a new pathogen of papaya (Carica papaya) in Peninsular Malaysia. Int. J. Mol. Sci. 12: 39-45.

McHale, L., Tan, X., Koehl, P. \& Michelmore, R.W. 2006. Plant NBS-LRR proteins: Adaptable guards. Genome Biology 7: 212.

Meunier, E. \& Broz, P. 2017. Evolutionary convergence and divergence in NLR function and structure. Trends Immunology 38(10): 744-757.

Mohd Azhar, H., Johari, S., Nur Sulastri, J., Razali, M., Muhammad Zulfa, M.R., Noor Faimah, G. \& Mariatulqabtiah, A.R. 2020. Field performance of selected papaya hybrids for tolerance to dieback disease. Journal of Tropical Agriculture and Food Sciences 48(1): 25-33.

Monteiro, F. \& Nishimura, M.T. 2018. Structural, functional, and genomic diversity of plant NLR proteins: An evolved resource for rational engineering of plant immunity. Annual Review of Phytopathology 56: 243-267.

Noman, A., Aqeel, M. \& Lou, Y. 2019. PRRs and NB-LRRs: From signal perception to activation of plant innate immunity. International Journal of Molecular Sciences 20(8): 1882

Padmanabhan, M., Cournoyer, P. \& Dinesh-Kumar, S.P. 2009. The leucine-rich repeat domain in plant innate immunity: A wealth of possibilities. Cellular Microbiology 11(2): 191-198.

Porter, B.W., Paidi, M., Ming, R., Alam, M., Nishijima, W.T. \& Zhu, Y. 2009. Genome-wide analysis of Carica papaya reveals a small NBS resistance gene family. Molecular Genetics and Genomics 281: 609-626.

Sekeli, R., Hamid, M.H., Razak, R.A., Wee, C.Y. \& Abdullah, J.O. 2018. Malaysian Carica papaya L. var. Eksotika: Current research strategies fronting challenges. Frontiers in Plant Science 9: 1380.

Sharma, R., Rawat, V. \& Suresh, C.G. 2017. Genome-wide identification and tissue-specific expression analysis of nucleotide binding site-leucine rich repeat gene family in Cicer arietinum (kabuli chickpea). Genomics Data 14 24-31.

Sokalingam, S., Raghunathan, G., Soundrarajan, N. \& Lee, S.G. 2012. A study on the effect of surface lysine to arginine mutagenesis on protein stability and structure using green fluorescent protein. PLoS ONE 7: e40410. 
Stanger, H.E., Syud, F.A., Espinosa, J.F., Giriat, I., Muir, T. \& Gellman, S.H. 2001. Length-dependent stability and strand length limits in antiparallel $\beta$-sheet secondary structure. PNAS 98: 12015-12020.

Steele, J.F.C., Hughes, R.K. \& Banfield, M.J. 2019. Structural and biochemical studies of an NB-ARC domain from a plant NLR immune receptor. PLOS ONE 14(8): e0221226.

Strickler, S.S., Gribenko, A.V., Gribenko, A.V., Keiffer, T.R., Tomlinson, J., Reihle, T., Loladze, V.V. \& Makhatadze, G.I. 2006. Protein stability and surface electrostatics: A charged relationship. Biochemistry 45: 2761-2766.

Supian, S., Saidi, N.B., Wee, C.Y. \& Abdullah, M.P. 2017. Antioxidant-mediated response of a susceptible papaya cultivar to a compatible strain of Erwinia mallotivora. Physiological and Molecular Plant Pathology 98: 37-45.

Tian, S., Yin, X., Fu, P., Wu, W. \& Lu, J. 2020. Ectopic expression of grapevine gene VaRGAl in Arabidopsis improves resistance to Downy Mildew and Pseudomonas syringae pv. tomato DC3000 but increases susceptibility to Botrytis cinerea. International Journal of Molecular Sciences 21(1): 193.

Wang, J., Chen, T., Han, M., Qian, L., Li, J., Wu, M., Han, T., Cao, J., Nagalakshmi, U., Rathjen, J.P., Hong, Y. \& Liu, Y. 2020. Plant NLR immune receptor Tm- $2^{2}$ activation requires NB-ARC domain-mediated self-association of CC domain. PLoS Pathogens 16(4): e1008475.

Wei, C., Kuang, H., Li, F. \& Chen, J. 2014. The $l 2$ resistance gene homologues in Solanum have complex evolutionary patterns and are targeted by MiRNAs. BMC Genomics 15: 743.
Zhang, Y., Xia, R., Kuang, H. \& Meyers, B.C. 2016. The diversification of plant NBS-LRR defense genes direct the evolution of MicroRNAs that target them. Molecular Biology and Evolution 33(10): 2692-2705.

Zhou, Z., Bar, I., Sambasivam, P.T. \& Ford, R. 2019. Determination of the key resistance gene analogs involved in Ascochyta rabiei recognition in chickpea. Frontiers in Plant Science 10(644): 1-12.

Nur Syazana Abu Bakar, Noor Baity Saidi* \& Mohd Puad Abdullah

Department of Cell and Molecular Biology

Faculty of Biotechnology and Biomolecular Sciences

Universiti Putra Malaysia

43400 UPM Serdang, Selangor Darul Ehsan

Malaysia

Lina Rozano \& Suhaina Supian

Biotechnology and Nanotechnology Research Centre

Malaysian Agricultural Research and

Development Institute (MARDI)

43400 Serdang, Selangor Darul Ehsan

Malaysia

Noor Baity Saidi*

Biodiversity Unit, Institute of Biosciences

Universiti Putra Malaysia

43400 UPM Serdang, Selangor Darul Ehsan

Malaysia

*Corresponding author; email: suhaina@mardi.gov.my

Received: 20 October 2020

Accepted: 21 January 2021 